\title{
NOVE, NOVENA E A ESCRITA EM “O PÁSSARO TRANSPARENTE", DE OSMAN LinS
}

RENATA Rocha RIBEIRO*

\section{Resumo}

O presente artigo aborda o lugar do volume de narrativas Nove, novena, publicado em 1966, na trajetória literária do escritor Osman Lins (19241978), bem como verifica como o tema da escrita é trabalhado em uma das narrativas que o compõem, intitulada "O pássaro transparente". Para isso, serão utilizados os pressupostos teórico-críticos de Andrade (1987), Nitrini (1987), Barthes (1987, 2004), Barbosa (1996), Paes (1994), Eco (2008), entre outros. Será observado que, no referido conto, a escrita cotidiana é abordada por intermédio da presença de cartas e do jornal. A escrita literária e a arte visual também se fazem presentes, por meio do tema do poeta frustrado, representado na personagem masculina, e da preparação para uma trajetória artística, representada na personagem feminina.

Palavras-Chave: Nove, novena, "O pássaro transparente", escrita.

Uma das pioneiras e mais respeitadas críticas da obra de Lins, Ana Luiza Andrade, em Osman Lins: crítica e criação (1986), identifica, por meio de Guerra sem testemunhas - volume de ensaios publicado pelo escritor pernambucano em 1969 - três fases de sua obra: a fase da procura, a da transição e a da plenitude. $O$ visitante, de 1955, Os gestos, de 1957, e O fiel e a pedra, de 1961, pertencem à primeira; Nove, novena, de 1966, à segunda e Avalovara, de 1973, e $A$ rainha dos cárceres da Grécia, de 1976, à terceira. Seus primeiros três livros de narrativa seriam de "procura", pois neles é percebida uma busca pela "conquista de um novo domínio na área da narrativa e do romance" (ANDRADE, 1987, p. 75). Além disso, observamos, em toda

* Professora Adjunta de Literatura Brasileira, de Estágio do Português e do Programa de Pós-Graduação em Letras e Linguística da Faculdade de Letras da Universidade Federal de Goiás (UFG), Goiânia, Goiás, Brasil. E-mail: renatarribeiro@yahoo.com.br. 
a trajetória narrativa da obra de Lins, uma preocupação fremente em relação aos temas da leitura e da escrita ${ }^{1}$. Desse modo, temos como objetivos, neste artigo, verificar o porquê de Nove, novena, volume composto por nove narrativas ${ }^{2}$, ser um marco na obra do escritor e como a narrativa "O pássaro transparente", contida nele, move questões relacionadas principalmente ao âmbito da escrita.

Em Guerra sem testemunhas, o duplo de Lins, Willy Mompou, afirma:

Se algo existe que continue a atrair-me no Drama é o rigor da construção, o cálculo com que se distribuem os acontecimentos, o artifício e o engenho com que urge preparar e solucionar a intriga. [...] A tendência a preparar com minúcias todos os meus trabalhos literários, com vistas a assegurar-lhes harmonia e unidade, perdura; minhas concepções, porém, tendem agora para o épico e se desligaram da subserviência à tradição do real; ou melhor, à tradição naturalista e estreita do real. Estou comprometido agora com outra espécie de realidade. (LINS, 1974, p. 104)

Essa nova relação com a realidade pode ser entendida como uma referência a Nove, novena, visto que Guerra sem testemunhas foi lançado em 1969, mas já estava sendo escrito por volta de 1966, quando Nove, novena foi finalizado e publicado. A nova forma de encarar a realidade por Lins não foi obra do acaso, mas de sua constante observação das coisas e dele mesmo, além de suas leituras, viagens e reflexões sobre a arte. Sandra Nitrini (2010) considera o diário de viagens Marinheiro de primeira viagem, de 1963, como uma espécie de anúncio do que o autor viria a realizar em Nove, novena e Avalovara, uma vez que já estão presentes aí aspectos relacionados a uma linguagem visual, fragmentada e o ornamentada, por exemplo.

Desse modo, Nove, novena indica, na trajetória osmaniana, um novo modo de se pensar a relação da produção literária com o seu contexto. É importante destacar que Lins não parecia acreditar na separação entre literatura e sociedade, o que podemos perceber praticamente em todos os capítulos de Guerra sem testemunhas. Para exemplificar, fiquemos apenas com uma frase sobre o escritor: "O escritor é impensável fora do contexto social” (LINS, 1974, p. 151). 
O próprio Lins, em entrevistas, afirmou esse novo caminho proposto por Nove, novena. Em 1966, à época de sua publicação, Mário Damotta questionou o autor se esse livro apresentava algo de novo em relação aos processos de criação literária, ao que Lins lhe respondeu:

Sim, há vários aspectos do livro que contrariam a tradição, e isto vem sendo assinalado com muita insistência pela crítica. É preciso esclarecer, porém, que essas inovações não foram procuradas. Elas não foram postas no livro gratuitamente, para chamar a atenção, para dar uma idéia de excentricidade. Estão ali porque foram necessárias e refletem minha visão do mundo e da literatura. [...] nos nove trabalhos reunidos em Nove, novena, reflete-se a minha verdade. $\mathrm{O}$ que sou, o que vejo, o que sinto. Assim, os métodos que empreguei vão refletir, com o máximo de precisão, exatamente isto. Se meu livro obedecesse a processos tradicionais de composição estaria traindo minha maneira de ver, não refletiria minha visão de mundo. (LINS, 1979, p. 134)

Essa resposta justifica o desvio intencional da tradição narrativa feito por Lins, visto que parte da crítica atribuiu muito à época esse aspecto, dando a entender que seria uma forma de "chamar a atenção" ou que a única contribuição desse livro seria a experimentação formal. Entretanto, por meio da leitura de seus ensaios, em especial os de Guerra sem testemunhas, percebemos que tudo faz parte de um plano concebido ao longo de muito tempo, fato que explica a chamada "fase da procura" osmaniana.

Ainda em 1966, ao ser entrevistado para o Correio da Manhã, jornal carioca, o entrevistador insistiu na dissociação entre autor e público provocada pelas inovações de Nove, novena, já que, nas palavras do jornalista, é uma "obra de leitura difícil ou exigente" e sem muitas "probabilidades de atingir o público" por sua "novidade". Em relação a isso, respondeu o autor:

Só há uma dissociação que o autor deve temer: é a dissociação entre si próprio e o real. E o caminho certo para essa dissociação é precisamente o academismo: o uso de fórmulas estereotipadas, que não o ajudam a captar o real e a nada conduzem. Em literatura, toda 
conquista árdua atinge o público, mais cedo ou mais tarde. E são essas conquistas que enriquecem o leitor, não os caminhos já conhecidos. [...] Se [...] Nove, novena abrange mais áreas de pesquisa, é que meu espírito permite agora essa aventura. [...] Considero-os, [os leitores] com o mais fundo respeito, substancialmente iguais a mim. E meu respeito por eles é que me faz enfrentar todas as dificuldades da criação. Tenho de oferecer-lhes o melhor de mim mesmo, o que há de mais puro, de mais original, de mais grave em mim. E nunca, em nenhuma hipótese, as sobras do meu espírito. (LINS, 1979, p. 137-138)

Portanto, por meio desses trechos, observamos que Lins admitia estar adentrando um novo período em seus textos, concretizando o que pesquisara. Este período tem como marco literário inicial o volume de narrativas em questão.

João Alexandre Barbosa, no memorável prefácio da primeira edição de Nove, novena, intitulado "Nove, novena novidade", assentiu que Lins, por meio da construção narrativa, procura:

a elaboração de uma linguagem que seja capaz de fisgar, em diferentes planos, partículas significativas da existência humana. Isto, que talvez se possa dizer a respeito de qualquer produto do trabalho criador literário, afirma-se, no entanto, como uma característica fundamental na obra de Osman Lins e lhe confere, verdadeiramente, a novidade com que completei, no título da Introdução, o título do livro. Porque não se trata apenas de uma série de contos, mas de exercícios de "écriture" orientados no sentido da formação de um universo ficcional que, como tal, inclui personagens, objetos, situações, tramas e significados que, entretanto, são percebidos pelo leitor enquanto intimamente dependentes do próprio ato de reorganização lingüística que lhes deu origem. É que, entre a percepção do mundo, projetado pela linguagem, e a assimilação da leitura, o autor obriga-nos a um encontro decisivo com todos os elementos de execução que configuram a construção do texto. Ele não conta; escreve. Mas, por este ato, cria um espaço em que se situa a fabulação. E faz surgir, então, a narrativa como se fora uma imposição inevitável decorrente do enlaçar-se e fundir-se das palavras, respondendo a indagações da sensibilidade ao encontro com a realidade. (BARBOSA, 1996) 
Barbosa chama a atenção para um aspecto que será abordado mais adiante, o de escritura, na acepção barthesiana. Isso porque, em relação à escrita, um dos aspectos que se destacam em Nove, novena é a homenagem tributada a essa atividade humana.

Em "Palavra feita vida", posfácio da segunda edição das narrativas, publicada em 1975, José Paulo Paes corrobora a visão de que o processo criativo de Lins tinha se voltado para a pesquisa de novas formas de expressão,

com vistas a exprimir mais consubstancialmente aquela momentosa visão de mundo que ia afeiçoando em seu espírito no limiar da idade madura e a que fez referência numa entrevista ${ }^{3}$. Longe de inculcar-se uma adesão superficial às modas de vanguarda, tratava-se de uma exigência imposta de dentro para fora pela própria dinâmica da sua criação literária. (PAES apud LINS, 1994, p. 201)

A questão formal, portanto, foi um grande destaque atribuído na inauguração dessa outra fase literária de Lins e a crítica seguiu esse caminho. Anatol Rosenfeld, em "O olho de vidro de Nove, novena", publicado em 1970, analisa a "nova forma" de Lins da seguinte maneira:

as radicais transformações de estrutura, que distinguem Nove, Nove$n a$ das obras anteriores, certamente não decorrem de cogitações e de ordem apenas "técnica" acerca de processos narrativos. Conquanto conscientemente elaborados ou pelo menos em seguida consciencializados pela reflexão estética, os novos processos não são resultado de um jogo "formal" gratuito, mas exprimem uma experiência mais profunda e mais pensada que a que se organizou nas obras anteriores, de feitio mais tradicional, mais próximas do romance psicológico legado pelo século XIX. São consequência, em última análise, de considerações ontológicas e antropológicas, de uma nova visão do homem e da sua relação com o universo e com a sociedade, visão que já não é captável, de forma adequada, pelas estruturas da narrativa tradicional. É, portanto, a necessidade de abordar esta nova experiência não apenas tematicamente, mas de assimilá-la à própria estrutura da obra, em termos estéticos adequados, para levar o leitor a participar (e não apenas a tomar conhecimento) dessa experiência, que forçou Osman Lins a renovar a sua arte de narrar [...]. (ROSENFELD, 1970) 
A leitura de Rosenfeld aponta para o caráter consciente da inovação formal na narrativa de Lins. Em outras palavras, seus novos processos narrativos não teriam sido mera experimentação pela própria experimentação. Para o crítico, Lins representou, formalmente, novos modos de pensamento e de relações humanas, sejam elas entre as próprias pessoas ou delas com seu meio, seu espaço.

De forma ampliada, consideramos Nove, novena, em relação aos temas da leitura e principalmente da escrita, como a possibilidade de realização do texto como prazer, por parte do leitor, e a realização de uma escritura, por parte do escritor. Particularmente, veremos como leitura e escrita se configuram especialmente em "O pássaro transparente".

Em Nove, novena, de modo geral, a escrita pode ser encarada como forma de continuação da vida, um tipo de registro, artístico ou não. E a leitura propicia, nos obstáculos propostos pelas inovações formais de Lins, que o leitor consiga participar e transpor tais barreiras. Pensemos, então, no leitor e no escritor, na leitura e na escrita, à margem do texto literário, para depois verificarmos suas inserções nele.

No oitavo capítulo de Guerra sem testemunhas, intitulado "O escritor e o leitor", Lins afirma que todo livro é dirigido a leitores, considerados como "invisíveis entidades" (LINS, 1974, p. 151). São invisíveis por não testemunhar o ato de criação da escrita, e também porque não seria possível precisar como é cada um deles, individualmente. Lins também acredita que a escrita pressupõe leitura: se não há leitor, não há escritor. O escritor não existe se escrever só para si: precisa de um público.

Nesse sentido, na relação entre autor, obra e leitor, percebemos que há pontos de contato com os modelos de autores e leitores de Umberto Eco, especialmente em Os limites da interpretação (2008b), visto que Mompou assente que

[c]ada escritor elabora [...] o seu leitor. [...] Esse leitor (não simples reflexo ou desdobramento do escritor), fruto da inteligência, da sensibilidade, do caráter, da concepção que tem o escritor do ofício e do mundo, é contemporâneo da gestação da obra; não nomeado, nela está presente, participa de sua natureza. (LINS, 1974, p. 152) 
Este pensamento acerca do leitor encontra bases na teoria do leitor modelo de Eco, que é aquele ideal previsto pelo autor modelo e pela obra em si. Lins chama esse leitor de "imaginário" e "ideal", e que:

[t]odo bom livro, por mais obscuro que pareça, é claro, desde que o abordemos devidamente. Infelizmente, nem sempre o crítico ou leitor reúne condições para a abordagem. Esta, de qualquer modo, não pode ser levada a cabo por um só indivíduo, é um ato longo e coletivo. (LINS, 1974, p. 153).

Em outras palavras, para Lins, o leitor ideal não é possível: não se pode, individualmente, realizar uma abordagem que abarque tudo o que o autor pensou ou tudo o que a obra permite inferir. Mais uma vez, há relação com Eco a respeito das suas intentiones, pois Lins considera que o livro, a obra "diz" algo (o "bom livro", mesmo "obscuro", é "claro"), além de contar com a abordagem do leitor, que, para ser ideal, deve ser coletivo.

Ainda neste capítulo de Guerra, Mompou destaca algumas das características que distinguem um bom leitor. De forma resumida, um bom leitor é aquele que vê, no ato de ler, uma necessidade humana; que além de se dedicar à leitura também faz releituras ${ }^{4}$; que é consciente da importância da literatura; que não vê a forma como mais importante que o conteúdo, e vice-versa; que faz leituras variadas, tanto do passado quanto do presente, sem necessariamente serem numerosas ou organizadas; que é aberto a novas experiências, mas sem considerálas a maior virtude de quem escreve; que é disciplinado, havendo uma continuidade em suas leituras. Conforme Mompou, esse leitor "não é apenas o correlativo dialético do ato de escrever: ele confirma e amplia o significado intrínseco da obra" (LINS, 1974, p. 155).

Por outro lado, Mompou também defende um tipo de leitura semelhante à superinterpretação de Eco (Interpretação $e$ superinterpretação, 2005), ou seja, uma leitura “equivocada". É o que indica quando diz que:

[u]m livro é escrito, inclusive, para os que o lêem indevidamente, para os que o estranham, os que o detestam e até para os que não haverão de o ler. Natural existirem pessoas que, não o lendo, venham a ser afetadas pelas suas páginas, quando outras, lendo-as, 
permanecerão imunes, insensíveis a todos os seus possíveis estímulos. (LINS, 1974, p. 155, grifo nosso)

Essa passagem corrobora a visão de que o leitor ideal não é um indivíduo, mas que a leitura ideal é a soma de leituras individuais e que, talvez, nem chegue a um fim (Mompou dá o exemplo de Hamlet: após mais de três séculos, não há uma "integral intimidade" com o texto). Além disso, as leituras indevidas são válidas por serem tentativas.

Em resumo, Guerra sem testemunhas constrói, ao longo de seus dez capítulos, uma ideia do escritor e do leitor. Quanto ao primeiro, é um combatente: vive um embate com a linguagem, com o mercado editorial, com a sociedade. $\mathrm{O}$ escritor deve possuir um plano para realizar sua obra, mesmo que ele mude ao longo da escrita. Também não devemos, e aqui há contato com Eco, buscar numa obra a intenção de quem a produziu, mas o que ela própria manifesta. Além disso, o escritor não deve se vender por ilusões, respeitando sempre sua produção. $\mathrm{O}$ ato de escrever é, ao mesmo tempo, solitário e social: para escrever o escritor precisa da solidão, mas sua escrita revela justamente a sua relação com a sociedade de que participa, a começar pelo uso do seu idioma. Por isso, escrever é estar numa guerra sem testemunhas.

Quanto ao leitor, é dado a ele o poder de participar ativamente do que lê (outra aproximação com Eco). O leitor não é um mero receptáculo da obra. Ele é, também, criador de sua leitura. Como Lins entende que o romance é um universo, escritor e leitor estão contidos nele, em troca constante.

Existem algumas características em Nove, novena, pensadas em relação ao leitor ideal, que esbarram nas peculiaridades do leitor empírico, aquele que realmente tem o objeto livro em suas mãos. Como observamos, as narrativas foram recebidas tanto com certo entusiasmo quanto com desconfiança pela crítica especializada e pelos leitores "comuns". Uma dessas características é a questão do ponto de vista. Tradicionalmente, temos a narração feita ou por um narrador externo aos acontecimentos ou por uma personagem. O leitor, então, acompanha praticamente um ponto de vista ao longo de todo o enredo.

O que Lins realizou foi a diluição dessa pretensa unidade: "diluí esse ponto com os sinais gráficos que ajudam a intercalar os diálogos. Mas os sinais gráficos são apenas um acidente. Eles são importantes 
apenas enquanto servem de instrumento para o que vou escrever" (LINS, 1979, p. 149). Assim, a mesma narrativa é mostrada por meio da diversificação dos pontos de vista. Como consequência, algumas personagens são mais desnudadas, outras não, mas conscientes de seu poder narrativo.

Além da diluição do ponto de vista, há a diluição do enredo. Sandra Nitrini, no seu estudo sobre Nove, novena e o nouveau roman, afirma que, apesar de haver história ${ }^{5}$ nas narrativas, principalmente sob o tema das relações humanas, suas estruturas são minimizadas devido à sua própria organização e à sua natureza, visto que não ocupam longos trechos, mostrando-se, "quase sempre, deslocadas para o fim e abafadas pelo movimento centrífugo do texto que se volta para trechos descritivos, alegóricos, insólitos e ornamentais" (NITRINI, 1987, p. 72).

Em outras palavras, estes trechos acabam ocupando mais espaço do que o enredo em si. Outra afirmação de Nitrini confirma esse fenômeno: "a poética osmaniana afirma a história como matéria-prima e nega-a enquanto instância primeira de suas narrativas, conseguindo como resultado um texto que é síntese de um discurso e de uma história pulverizada" (NITRINI, 1987, p. 72).

Mais uma questão relacionada às categorias narrativas é a do tempo. Em Nove, novena, devido à estrutura retabular ${ }^{6}$, o tempo parece se fundir: não há grande diferenciação entre passado, presente e futuro, pois são colocados lado a lado, como quadros de um retábulo. É justamente essa justaposição que promove a destemporalização, fazendo com que o que aconteceu, o que ocorre e o que está por vir pareçam uma unidade.

Énatural, por conseguinte, que umleitor empíricoacostumado com uma narrativa de enredo, cujas demais categorias são bem delimitadas, estranhe a proposta de Nove, novena. Não há duvidas de que o leitor modelo de Lins, para este livro, deva ser mais experimentado, exigente e ao mesmo tempo aberto a novas possibilidades narrativas. E aqui não falamos apenas da leitura em seus estágios iniciais, da codificação ao juízo de valor, mas do conhecimento um pouco mais específico do texto literário, de suas peculiaridades. Isso porque o enredo de cada narrativa desse livro pode ser resumido em poucas linhas, entretanto, é o aspecto ornamental, a construção matemática que salta aos olhos de quem lê. 
A estrutura retabular, portanto, aparece ao leitor como uma espécie de quebra-cabeças que ele deve montar em sua mente. É uma leitura participativa, em que o leitor realmente deve preencher os interstícios do texto, estabelecer as ligações entre um quadro e outro, entre passado e presente, entre um espaço e outro.

Buscando algumas definições de Barthes em O prazer do texto, a nova fase osmaniana corresponderia ao texto de fruição, pois a proposta de Nove, novena não é a de confortar o leitor, mas colocá-lo em dúvida, promover uma crise na "sua relação com a linguagem" (BARTHES, 1987, p. 21-22). Não estamos aqui querendo fazer a apologia de que Lins "inventou" tais aspectos, até mesmo porque essas "inovações" foram fruto de sua pesquisa e de seu contato com a cultura europeia, em especial a francesa, de onde muito se procurou as semelhanças com o novo romance. Entretanto, no contexto brasileiro, Lins foi um daqueles que se aventurou nesse tipo de narrativa em que o veículo é a viagem ${ }^{7}$.

Ao citar o prefácio de João Alexandre Barbosa, dissemos que iríamos comentar sobre a questão da escritura. Sandra Nitrini também destaca essa questão, afirmando que as narrativas de Nove, novena enfatizam "sua identidade mais como texto do que como estrutura narrativa, [valorizando] mais a escritura do que a aventura" (NITRINI, 1987, p. 72, grifo da autora). Os termos grifados são uma referência ao novo romance francês. Porém, o conceito de escritura a que vamos aludir é o de Barthes em $O$ grau zero da escritura. Não vamos nos ater detalhadamente na evolução do conceito de escritura ao longo das obras de Barthes ${ }^{8}$, visto que nosso intuito é observar como ele reflete na noção de escrita depreendida de Nove, novena.

Conforme Barthes (2004, p. 9), a escritura é um conceito formal independente do de língua e do de estilo. Em resumo, a língua faz parte de uma configuração histórica, anterior ao escritor, um fenômeno social, não individual. Já o estilo faz parte da "mitologia pessoal e secreta do autor", com "dimensão vertical" e "origem biológica" (BARTHES, 2004, p. 10), ou seja, também é algo que antecede o ato de escrever. A escritura, por sua vez, estaria entre a dimensão horizontal da língua e a dimensão vertical ${ }^{9}$ do estilo: é a escolha do autor diante do que a língua e o estilo lhe fornecem. Assim, como lembra Leyla PerroneMoisés (2005, p. 30, grifo da autora), "a escritura é uma questão de enunciação" e, para ela, em O grau zero, 
Barthes nos diz que a escritura é uma questão de tom, de recitação (débit), de finalidade, de moral. A escritura é, ao mesmo tempo, uma modulação da fala e uma modalidade ética. Escritores contemporâneos dispõem da mesma língua, vivem a mesma história, mas podem ter escrituras totalmente diferentes porque a escritura depende do modo como o escritor vive essa história e pratica essa língua.

De acordo com essas definições, estilo e escritura partilham de algo semelhante, que é a escolha. Como então separá-los? Essa diferenciação, de acordo com Perrone-Moisés (2005, p. 31), só será possível se for analisada a "evolução" do conceito, desde $O$ grau zero até $O$ prazer do texto, visto que, desde o início, o conceito de escritura revela uma ambiguidade, que está no compromisso do escritor com a sua história. Segundo Barthes, a escritura nasce, de um lado, do confronto do escritor com a sociedade e, de outro, da remissão às suas fontes de criação. Logo, a escritura, presa entre dois tempos,

está igualmente amarrada a dois objetivos aparentemente contraditórios: dizer a história (voltar-se para o mundo) e dizer a literatura (voltar-se para ela mesma). A auto-reflexividade da escritura implica, ao mesmo tempo, renunciar a um referente e a um destinatário exteriores. A escritura não é uma forma de comunicação. [...] Nesse ponto se evidenciam as diferenças entre a fala, estudada pela lingüística, e a escritura. A fala é instrumental, a escritura não, e este ponto [...] será radicalizado nos escritos subseqüentes de Barthes. (PERRONE-MOISÉS, 2005, p. 32)

Segundo Nitrini (1987, p. 52, grifo da autora), o tempo da escritura, no contexto do nouveau roman, é aquele em que "o discurso adquire maior importância e passa a transcender a história", de tal maneira que "desaparece a preocupação característica da narrativa tradicional de esconder o trabalho do escritor".

Isso nos lembra a metaficcionalidade ou autorreflexividade atribuída a Lins em seus textos ficcionais, especialmente a partir de Nove, novena. Entretanto, esse trabalho artesanal com a forma, de acordo com o que Lins deixou claro em entrevistas e no próprio Guerra, não deveria distanciar a obra dos leitores, muito menos demonstrar uma falta de compromisso do escritor com sua realidade. 
Assim, o conceito barthesiano de escritura mantém pontos de contato com a proposta de escrita em Nove, novena. Por outro lado, nega o que Lins tinha como plano literário. Vemos, nas narrativas, a tentativa de "dizer a história" e de "dizer a literatura", mas sem a renúncia dos referentes ou destinatários exteriores. Em "O pássaro transparente”, por exemplo, verificamos como um dos motivos de fundo a diferença entre a vida no interior e na capital, no caso, Recife.

Não pensamos que Lins encarava sua literatura como não comunicativa, até mesmo porque, como dissemos acima, as suas "inovações" exigem a participação dos seus leitores. Leitores despertos. O fato de impor obstáculos, propor enigmas e alegorias pode não facilitar uma "comunicação fluente", mas não deixa de chamar a atenção para o esforço de quem lê, a fim de que não seja um mero receptáculo. Quem lê é uma parte ativa dos processos que envolvem a literatura, como entende Eco (2008a, p. 36) ao afirmar que a leitura é um movimento cooperativo, isto é, o leitor contribui para que os sentidos não fiquem somente na obra.

Do ponto de vista da escrita, portanto, Nove, novena como um todo é um elogio da escritura no sentido de ser discurso, de ser literatura, de não ocultar o trabalho artesanal do escritor, no próprio corpo textual, que se revela nas características elencadas anteriormente. Por meio das rupturas propostas em relação à narrativa tradicional, ou, como afirma Lins em Guerra (1974, p. 152), aos "caminhos familiares", tenta valorizar o labor de quem cria, do escritor de fato, que é aquele que "concebe a leitura como um ato vivificante e escreve seus livros com vistas a essa possível relação" (LINS, 1974, p. 153).

Por conseguinte, essa valorização do trabalho do escritor, da enunciação, é um elogio da linguagem literária, do código e, em alguns momentos, como resultado da relação entre enunciação e código, poderíamos dizer que ocorre a miseenabymedo código ou metatextual, segundo a acepção de Lucien Dällenbach em Le récit spéculaire (1977), que a entende como a reflexão textual da obra sobre ela mesma. Tal estrutura em abismo, especialmente, acontece em relação a alguns símbolos e aos ornamentos presentes na narrativa de Lins, que não são discutidos por um narrador, mas fundidos no corpo do texto.

Dados esses comentários sobre a leitura e a escrita ao redor de Nove, novena, adentremo-nos na obra e vejamos como os temas estão 
presentes nela. Pensamos que, devido ao fato de esse volume ser um divisor de águas na ficção osmaniana e uma espécie de ode ao trabalho do escritor, o tema da escrita é bem mais presente que o da leitura, via construção narrativa e personagens. Nesse sentido, pensamos que Nove, novena trata da escrita como modo de perpetuação, de continuação, de registro, sejam artísticos ou não, e a leitura, por conseguinte, é o modo de acessar o que deve ser propagado. Seja por meio do mote do escritor frustrado ou da exposição do escritor em busca da vocação, do caráter fixador da escrita, da leitura de textos e imagens, do entalhe da escrita, Lins faz seu tributo ao mundo das letras nesse volume. A partir daí, vejamos então como os temas em questão se relacionam na narrativa "O pássaro transparente".

"O pássaro transparente" é a primeira narrativa do volume e tem como centro a vida de um homem, inominado. Cada parágrafo é um quadro de sua vida, alternados entre infância, adolescência e fase adulta. $\mathrm{O}$ foco narrativo também sofre oscilação, há quadros tanto na terceira quanto na primeira pessoa. É o embate de um menino que, ao se tornar adolescente, luta contra as imposições paternas, mas que, ao se ver adulto, a caminho do funeral do pai, percebe que cumpriu todas elas e deixou de lado suas aspirações, seus sonhos. É o que pensa, ao encontrar o pai morto:

Pois é, meu pai. Há muitos anos queria vê-lo assim, as vontades cortadas, sem poder, sem voz autoritária, desde o dia em que, desamparado, senti sua inclemência e decidi voltar. Havia, dentro do senhor, um morto: este. [...] Pois bem, eu recebi a herança. Renunciei, para sempre, a qualquer expressão pessoal do ato de viver. Desposei a mulher que o senhor decidiu ser a indicada para mim, estou impregnado de tudo que detesto, corrompi-me, gosto de ser respeitado, dono de riquezas que haverão de crescer, trago o senhor em mim, nunca deixarei esta cidade. Sou o continuador, o submisso, o filho. O pai. (LINS, 1994, p. 12-13)

Nessa submissão, percebemos que em seu matrimônio fortunas foram somadas, deixando para trás seu amor de adolescência. Eudóxia, sua esposa, simboliza a vitória da tradição em detrimento dos sonhos de juventude, representados pela namorada da adolescência. Esta, por sua vez, tornou-se uma artista plástica renomada, realizando tudo aquilo 
que a personagem central queria para si, como ser artista (no caso dele, poeta) e viajar para a Europa.

A primeira menção à escrita e também à leitura nesta narrativa está nas cartas rasgadas pelo homem numa viagem de trem. Este ato é lembrado por ele quando está de volta à sua cidade para o funeral do pai: "Há quantos anos, neste mesmo trem, rasguei aquelas cartas, uma a uma?" (LINS, 1994, p. 10).

Neste momento, não se sabe que cartas são essas, mas adiante o leitor tem conhecimento de quem são: "Sou a mesma adolescente de quem você, um dia, rasgou as cartas no trem" (LINS, 1994, p. 14). Ou seja, as cartas eram da ex-namorada. O ato de rasgá-las pressupõe o período do rompimento de ambos, possivelmente quando o homem decidiu retornar à casa paterna. É como se, por meio de uma ação, a de rasgar, fosse também possível quebrar, exterminar o sentimento que por ventura tivesse motivado a escrita dessas missivas. Rasgar as cartas seria extirpar os vínculos afetivos reforçados pela escrita, impedir que o sentimento permanecesse com o passar do tempo, fixado no papel.

Mais à frente, há um reencontro entre o antigo casal. No diálogo, o homem diz que, ao fazer sua leitura dos jornais, sempre vê o nome da mulher:

- Tenho visto seu nome nos jornais. Li que você obtivera uma bolsa na Espanha. Fiquei contente, disse comigo: "Ora veja, quem podia imaginar que ela ia se tornar uma artista famosa". O jornal reproduzia uns quadros seus, frutas, pássaros voando. Um era transparente, via-se o pássaro e o coração do pássaro. Tinha um jeito de ave de rapina.

- E olhar de gente.

- Isso mesmo. Era assustador. Existe, aquele pássaro?

- Não. (LINS, 1994, p. 13)

Para ele, era uma surpresa que a mulher realizasse seu antigo desejo de ser artista e viajar pelo mundo, já que ela não desenhava antes. $\mathrm{O}$ fato de o homem observar que ela não desenhava antes fez a mulher confessar que escrevia versos, mas que nunca os havia mostrado. $\mathrm{O}$ homem também se lembra de ter escrito versos: "Sabe que num dia desses, abrindo uma gaveta, encontrei também versos meus? Incrível. 
Não me lembrava deles. Como a gente muda, hein?" (LINS, 1994, p. 14). Mais tarde, saberemos que ele mostrava seus versos a ela na época em que namoravam. Desse modo, vemos que os dois, durante a juventude, partilhavam de gostos semelhantes.

É interessante, aqui, verificar a relação entre o título desta narrativa e o diálogo entre o casal transcrito acima. O pássaro transparente está num quadro da mulher, um misto de ave e ser humano, pois era o corpo de um pássaro com o olhar de um homem. Além disso, outro elemento é surpreendente: a ave, por ser translúcida, permite a visão de seu coração. Assim, dois elementos, um que pode ser relacionado ao racional, que é o olhar firme, e outro que pode ser ligado ao sentimental, que é o coração, se fundem nesse ser ambíguo. É uma possibilidade entender esse animal como uma espécie de símbolo do projeto estético de Lins ${ }^{10}$ : um misto de claridade e mistério, fruto de observação racional e sentimental. É a concretização do objeto artístico.

Além disso, por meio do diálogo entre o homem e a mulher, depreendemos o motivo da relação entre a arte e a realidade palpável. Quando o homem pergunta se aquela ave existe, ela responde que não, retomando assim uma das mais antigas contendas teóricas quanto à arte, a da relação entre ela e o mundo que a cerca. Entretanto, há pontos de contato entre esses dois mundos, visto que a arte é uma forma de questionamento e entendimento dessa palpabilidade. Como observa Nitrini (1987, p. 130), esse amálgama de traços humanos e animais contido no quadro da artista (ou de traços humanos e de objetos) reflete o que Lins realiza em várias das personagens de Nove, novena. $\mathrm{O}$ menino de "Pastoral", por exemplo, se denomina como feito de "cipós trançados": é um ser tecido. Como o cipó é matéria prima de objetos artesanais, o menino é trançado também de palavras, visto que é parte de um trabalho literário. Aliçona, moça que para o menino é um ser andrógino, "lembra um tronco nodoso, cinza e verde, grosso, coberto de limo” (LINS, 1994, p. 137-138). O cavalo que irá se juntar à sua égua Canária é imaginado pelo garoto como um "cavalo de cactos, crinas de agave, rabo de carrapichos" (LINS, 1994, p. 138). Este processo de composição (e aqui entendemos composição também no sentido de junção, justaposição de partes) de personagens se repetirá nas obras posteriores de Lins. 
Depois da separação, na adolescência, o homem e a mulher seguiram rumos diferentes. Um dos fatores que os unia era o gosto pela arte, no caso, a literatura: ambos escreviam versos, o que pressupõe a leitura de poetas. Só que havia uma diferença: enquanto ele mostrava seus versos a ela, crente de que um dia seria um famoso poeta e atravessaria o oceano, ela mantinha os seus em segredo, muito provavelmente amadurecendo em si o talento para as artes, e conseguindo, posteriormente, o que era almejado pelo outro. Ironicamente, tudo o que ele pensa que irá concretizar, durante sua juventude, e o que vai acontecer com a namorada, acaba sendo trocado:

[...] Mas quem sabe se não havemos de fazer os dois, um dia, nossa viagem?

Havemos. Ela diz havemos. Eu, não tu, farei essa viagem. Não sabes o que disse um poeta, desiludindo a sua namorada, decerto parecida contigo e que imaginava continuar ligada para sempre a ele? "Eu sou Goethe!" Também sou alguém, serei um nome, sinto força em mim. Conforto, dinheiro do pai, família, cidade natal, tudo abandonarei. O que sou destinado a conquistar, desconheço ainda. Mas sei que um dia voltarei aqui, rodeado de glória. Teu marido será empregado no comércio, ou talvez escrevente no cartório, terás um lar e filhos; mas teu orgulho maior, a ninguém confessado, virá de seres o que és agora: a testemunha de minha adolescência. Eu sou Goethe. (LINS, 1994, p. 16, grifo do autor)

Todo esse ímpeto cairá e é ele quem será o comerciante e pai de família, enquanto ela conquistará a glória artística. Notamos que a citação de um trecho biográfico de Goethe funciona como uma pequena história dentro de outra. Essa alusão poderia ser lembrada como uma mise en abyme do enunciado, segundo Dällenbach, que também é chamada de ficcional. Ela pode ser entendida como um conteúdo intertextual, ou seja, um enunciado que espelha outro enunciado, sem deixar de fazer parte do enunciado que o contém. Só que aqui parece ser realizada uma mise en abyme do enunciado às avessas, pois há uma semelhança entre a história contida e a continente, que é o namoro de dois casais de adolescentes, entretanto, o desfecho de ambas é totalmente diferente: Goethe de fato se afirmou como poeta consagrado, enquanto que em "O pássaro transparente" é a mulher quem se consagra. A visão desse 
jovem em relação ao seu futuro glorioso como poeta é bem romântica, não só em sua inspiração em Goethe, mas também no sentido de ter a certeza de que será grandioso, um verdadeiro gênio, diferente de tudo aquilo que seria se não fosse um poeta.

Após presentificar o momento de seu casamento, em que coloca Eudóxia como apegada a bens materiais, por mais insignificantes que fossem, o homem começa a procurar os papéis, aqueles em que escrevera seus versos, lembrados por meio de sua leitura do jornal e do diálogo com a ex-namorada. Ao encontrar e observar as poesias, não as reconhece "os mesmos olhos que as testemunharam" (LINS, 1994, p. 18). Ou seja: há um abismo entre o adolescente, o jovem que produziu aqueles versos e o adulto. Tudo que eles representavam não se cumpriu. A partir daí, o homem tece reflexões sobre seus antigos escritos:

Poesias. Por que, tantos anos passados, ainda as conservo? São meus poemas; em todo caso, não insuportáveis e neles perpassam alguma generosidade, alguma febre. Eu não era, porém, um coração limpo; reconheço que viviam nele, desde esse tempo, muitos dos repulsivos bichos que a diligência de meu pai nutriu e que fazem de mim, hoje, um viveiro sombrio. Fosse de outro modo, não seria com desdém, condescendência e orgulho que mostraria a ela esses trabalhos. (LINS, 1994, p. 18, grifo do autor)

A conservação dos poemas revela que, de um modo ou de outro, ainda tinham importância para o homem, ao contrário das cartas da exnamorada, que foram destruídas. Ou então, as cartas não foram poupadas para que seu passado ao lado da artista nunca viesse à tona, que ficasse somente na mente dela, uma testemunha de sua adolescência, como pensou no episódio em que cita Goethe. Mesmo depois de tantos anos, não havia deixado seu orgulho de lado: ainda acreditava que os versos não eram maus. Entretanto, eles estavam guardados no armazém, não em casa, talvez por receio de que Eudóxia os encontrasse e percebesse as intenções literárias da juventude dele.

De qualquer forma, o homem de "O pássaro transparente" revela o tema do escritor frustrado, que tinha planos, quando jovem, de se sagrar como um grande artista da palavra, mas que, de fato, seguiu os passos do pai. Nesta narrativa, o homem se torna impotente ante 
os desígnios do pai, não teve força para sustentar sua partida e, como o filho pródigo da parábola bíblica, retornou a casa para não ter de enfrentar o mundo. A escrita desse homem, de algum modo, fazia parte da ruptura contra os valores impostos pelo seu pai, mas no fim ficou esquecida dentro de uma gaveta.

Desse modo, o tema do escritor frustrado pode ser visto por meio do protagonista dessa narrativa. Por sua vez, uma leitura crítica pode ser visualizada na protagonista feminina de "O pássaro transparente". O leitor empírico não toma conhecimento do julgamento dela em relação aos versos do namorado de adolescência. Contudo, o homem afirma, como transcreveremos adiante, que a leitura demorada da moça era de "sondagem". Ora, se os anos e os acontecimentos subsequentes lhe deram essa certeza, é porque a então adolescente tinha um olhar crítico sobre os versos do namorado. Não se sabe, somente, se a crítica era positiva ou negativa, mas depreendemos que a mulher de " $O$ pássaro transparente" apurou seu senso estético e se tornou uma artista plástica.

Observamos, até então, que em "O pássaro transparente" há a referência direta a três tipos de textos escritos: a carta, o jornal e o poema. Mas há também a alusão ao cartão postal. Como vimos, as cartas são as escritas pela ex-namorada, lidas e rasgadas pelo homem. O jornal apenas é citado como parte da leitura diária dele, e é a forma por meio da qual se tem a notícia de que a moça se tornou uma artista renomada. Assim, o suporte jornalístico, por sua especificidade, autoriza esse renome, essa consagração. Seria diferente, por exemplo, se ele tivesse tido acesso ao fato de ela ter se tornado pintora por meio de uma conversa informal.

O cartão postal é um pedido do homem à ex-namorada: ele desejava ter um com os ciganos de Granada, que ela deveria enviar quando estivesse na Espanha. Já os versos são escritos tanto por ele quanto por ela na adolescência. A diferença, como entendemos, é que ele mostrava a ela os versos que escrevia, enquanto ela mantinha os seus em segredo. Na continuação do trecho citado acima, o homem comenta sobre a leitura dela:

Lembro-me de como prolongava a leitura. Eu imaginava ser por incompreensão, quando seu demorado olhar era de sondagem. Ela 
rebuscava meus versos, alegrava-se com eles, acreditava em mim. E não fui eu quem, afinal, quebrou a casca, descobrindo um modo criador e livre de existir. Ela amestrou as mãos da sua juventude, fez com que lhe pertencessem. Quanto a mim - estas, cautelosas, quase sempre fechadas, não sei que sutil e laborioso processo as engendrou - em que armário do tempo, em que espessa noite de interrogações perdi as minhas? (LINS, 1994, p. 18-19)

O orgulho em relação aos próprios versos fazia com que o jovem acreditasse que a namorada não os entendia bem, visto que prolongava $o$ ato de ler. Nem sempre demorar a ler significa falta de entendimento. Essa "dispersão" é o momento em que fazemos relações com tudo aquilo que trazemos conosco e que se relaciona, de algum modo, ao que lemos.

A leitura demorada pode, inclusive, indicar justamente o contrário da incompreensão: nesse caso, a moça realizava uma leitura de sondagem, crítica. Por meio da leitura dos versos dele, e provavelmente dos poetas já reconhecidos, ela foi capaz de educar o seu olhar e o seu entendimento para a arte. A leitura, para ela, pode ter funcionado como prática construtiva de seu projeto artístico, que mais tarde se revelou na pintura.

As referências à figura do pássaro retornam nesse último parágrafo da narrativa, por meio das expressões "quebrou a casca" e "livre". A moça foi capaz de quebrar a casca, ou seja, de nascer para a arte, de voar livremente para seguir seus sonhos. Ela se tornou artista e iria atravessar o oceano. Além disso, nessa passagem, percebemos que o artista nasce de uma inclinação ou vontade, isto é, a moça em sua juventude escrevia versos, mas o tempo, a dedicação, o trabalho é que fazem com que as mãos do artista sejam amestradas, capazes de produzir o que queria; no caso dela, as pinturas. Aí está uma das crenças de Lins em relação ao trabalho do escritor: não há somente o gênio, mas também e, sobretudo, o labor.

A partir das considerações feitas, entendemos, por fim, que a obra Nove, novena ocupa um lugar de destaque na obra de Osman Lins, figurando como uma espécie de plataforma que impulsionou também os rumos para os romances subsequentes, Avalovara e $A$ rainha dos cárceres da Grécia. Ademais, também destacamos a relevância do tema 
da escrita na obra literária de Lins em geral, com o exemplo pontual de Nove, novena e de "O pássaro transparente". Logo, na narrativa em questão, a escrita é vista do ponto de vista cotidiano, por meio das cartas e do jornal, bem como do ponto de vista artístico, por meio do tema do poeta frustrado (protagonista masculino) e da preparação para uma trajetória artística (protagonista feminina).

NINE, NOVENA AND WRITING IN “THE TRANSPARENT BIRD" ${ }^{11}$, BY OSMAN LiNS

\section{ABSTRACT}

This article aims to address the place of Nine, novena, published in 1966, in the literary trajectory of the Brazilian writer Osman Lins (1924-1978), as well as to verify how the writing theme is worked in one of the narratives that composes it, entitled "The transparent bird." To this end, it will be used the theoretical and critical assumptions by Andrade (1987), Nitrini (1987), Barthes (1987, 2004), Barbosa (1996), Paes (1994), Eco (2008), among others. It will be observed, in the short story, how everyday writing is approached through the presence of letters and the newspaper. The literary writing and the visual art are also present, through the theme of the frustrated poet, represented in the male character, and the preparation for an artistic trajectory, represented in the female character.

Keywords: Nine, novena, "The transparent bird", writing.

NOVE, NOVENA Y LA ESCRITA EN “O PÁSSARO TRANSPARENTE”, DE OSMAN LINS

\section{RESUMEN}

Este artículo tiene como objetivo analizar el lugar del volumen de narrativas Nove, novena, publicado en 1966, en la trayectoria literaria del escritor brasileño Osman Lins (1924-1978), así como verificar cómo el tema de la escritura se trabajó en una de las narrativas que lo componen, titulada " $\mathrm{O}$ pássaro transparente”. Para eso, se utilizarán los supuestos teóricos y críticos de Andrade (1987), Nitrini (1987), Barthes (1987, 2004), Barbosa (1996), Paes (1994), Eco (2008), entre otros. Será observado que, en el referido cuento, la escritura cotidiana es abordada por intermedio de la presencia de cartas y de periódicos La escritura literaria y el arte visual también se hacen presentes, por medio del tema del poeta frustrado, representado en el personaje masculino, 
y de la preparación para una trayectoria artística representada en el personaje femenina.

Palabras-Clave: Nove, novena, "O pássaro transparente", escrita.

\section{Notas}

1 Desenvolvemos, em nossa tese de doutorado, intitulada Leitura e escrita na narrativa de Osman Lins, o adensamento dos temas da leitura e da escrita na seguinte sequência narrativa do autor: O visitante (1955), Nove, novena (1966), Avalovara (1973) e A rainha dos cárceres da Grécia (1976). O presente artigo é uma versão da análise de "O pássaro transparente" realizada neste trabalho.

2 Optamos por usar "narrativas" ao invés de "contos" em respeito a essa denominação dada pelo próprio autor.

3 Essa entrevista pode ser a que Lins concedeu ao Diário de Pernambuco em 9 de outubro de 1966, em que disse: "Mas o Nove, novena inaugura uma fase de maturidade, talvez de plenitude, em minha vida de escritor. Com ele (no momento em que alcanço a quarentena), suponho haver resolvido problemas literários que há anos me perseguiam e conquistado uma expressão pessoal" (LINS, 1979, p. 141).

4 Em postura semelhante à de Calvino em "Por que ler os clássicos".

5 Aqui tomamos o termo "história" na acepção do termo "fábula" do formalismo russo, em oposição a "discurso", ou "trama". Para Tomachevski, a fábula (história) é o conjunto de acontecimentos ligados entre si, ou seja, é o enredo. Já a trama (discurso) é a forma por meio da qual o leitor toma conhecimento da fábula, ou seja, é o modo como são narrados os acontecimentos.

6 Quanto à estrutura retabular de Nove, novena, cabe uma observação. A única narrativa de se coloca como um retábulo perfeito é a que leva em seu título o nome dessa manifestação pictórica: "Retábulo de Santa Joana Carolina". Entretanto, Nitrini (1987) classifica as demais narrativas como "retábulo em embrião" ("Os confundidos", "Noivado", "O pássaro transparente" e "Um ponto no círculo"), "retábulo móbile" ("Conto 
barroco ou unidade tripartita") e "retábulo entrecruzado" ("Pentágono de Hahn" e "Perdidos e achados").

7 Para Monegal, em "Tradição e renovação", a narrativa latino-americana do século XX conheceu três grandes momentos de ruptura, dentre eles o das décadas de 1960-1970. Ao falar do romance, Monegal assente que a linguagem narrativa é o veículo da narração e a narração em si. Assim, o "meio é que é a mensagem" (MONEGAL, 1979, p. 159)

8 Para isso, conferir o livro Texto, crítica, escritura, de Leyla PerroneMoisés, especialmente o capítulo "Crítica e escritura".

9 Aqui nos lembramos da dicotomia saussuriana entre sintagma e paradigma. A língua, de caráter horizontal, seria uma estrutura sintagmática, enquanto que a verticalidade do estilo lhe dá caráter paradigmático. Se o estilo está para o paradigma, é porque pressupõe escolha por parte do escritor.

10 Depreendido, além das narrativas, também de suas entrevistas e de seus ensaios.

11 Utilizamos aqui os títulos traduzidos por Adria Frizzi para o inglês. LINS, Osman. Nine, novena. Trad. Adria Frizzi. Los Angeles: Sun \& Moon Press, 1995.

\section{REFERÊNCIAS}

ANDRADE, A. L. Osman Lins: crítica e criação. São Paulo: HUCITEC, 1987. BARBOSA, J. A. Nove, novena novidade. Prefácio da primeira edição de Nove, novena, 1966. Disponível em: <http://www.osman.lins.nom.br/repercursao. asp?id=p2>. Acesso em: 10 mar. 2016.

BARTHES, R. O prazer do texto. São Paulo: Perspectiva, 1987.

. O grau zero da escrita. São Paulo: Martins Fontes, 2004.

DÄLLENBACH, L. Le récit spéculaire: essai sur la mise en abyme. Paris: Seuil, 1977.

ECO, U. Interpretação e superinterpretação. Tradução MF. 2. ed. São Paulo: Martins Fontes, 2005.

. Lector in fabula: a cooperação interpretativa nos textos narrativos.

Tradução Attílio Cancian. 2. ed. 2 reimp. São Paulo: Perspectiva, 2008a. 
. Os limites da interpretação. Tradução Pérola de Carvalho. São Paulo: Perspectiva, 2008b.

LINS, O. Evangelho na taba: outros problemas inculturais brasileiros. São Paulo: Summus, 1979.

. Guerra sem testemunhas: o escritor, sua condição e a realidade social. São Paulo: Ática, 1974. . Nove, novena. 4. ed. São Paulo: Companhia das Letras, 1994.

MONEGAL, E. R. Tradição e renovação. In: MORENO, C. F. (Org.). América Latina em sua literatura. São Paulo: Perspectiva, 1979. p. 131-159.

NITRINI, S. Poéticas em confronto: Nove, novena e o Novo Romance. São Paulo: HUCITEC; Brasília: INL, 1987.

. Transfigurações: ensaios sobre a obra de Osman Lins. SP: Editora Hucitec, 2010.

PAES, J. P. Palavra feita vida. In: LINS, O. Nove, novena. 4. ed. São Paulo: Companhia das Letras, 1994.

PERRONE-MOISÉS, L. Texto, crítica, escritura. 3. ed. São Paulo: Martins Fontes, 2005.

ROSENFELD, A. O olho de vidro de Nove, novena. O Estado de São Paulo, São Paulo, 6 de dezembro de 1970, ano 15, no 699. Suplemento Literário. Disponível em: <http://www.osman.lins.nom.br/repercursao.asp?id=s7>. Acesso em: 21 set. 2016.

TOMACHEVSKI, B. Temática. In: EIKHENBAUM et al. Teoria da literatura: formalistas russos. 2. imp. Tradução Ana Mariza R. Filipouski et al. Porto Alegre: Globo, 1973. p. 169-204.

Submissão em 15 de março de 2016.

Aprovado em 20 de setembro de 2016.

Publicado em 29 de setembro de 2016 
